\title{
Effectiveness of Locust Bean Pod Solution (LBPS) in the Production of Sandcrete Blocks for Buildings
}

\author{
J. I. Aguwa*, B. Alhaji, A. Jiya. D. H. Kareem \\ Department of Civil Engineering, Federal University of Technology, Minna, Nigeria.
}

\begin{abstract}
Locust beam pod solution (LBPS) was prepared by extraction from the outer leathery cover of the pod soaked in water for twenty four hours in ten different concentrations of known weight of dried locust bean pod cover in 20 litres of clean water. Using ten levels of these concentrations, five sandcrete blocks of size 150mm cube were produced for each concentration, making a total of fifty blocks and the compressive strengths at 28 days were determined. Using a concentration of $50 \mathrm{~g} / \mathrm{l}$, twenty blocks were produced with $0,5,10,15,20,25,30,35$ and $40 \%$ respectively by weight of cement reduced making a total of 180 blocks. They were subjected to compressive strength test on 7, 14, 21 and 28 days respectively, crushing five blocks in each day to determine their average compressive strength. In order to investigate the effect of duration of soaking the locust bean pod cover in water on the compressive strength of the sandcrete blocks, five blocks were produced using the same concentration of $50 \mathrm{~g} / \mathrm{l}$ but soaked in water for $1,2,3,4,5,6,7,8,9$ and 10 days respectively and their compressive strengths were determined at 28 days. It was found that the higher the concentration of the LBPS, the more the compressive strength and soaking the locust bean pod cover for more than 24 hours is not necessary as the compressive strength tends to decrease. In conclusion, up to $25 \%$ by weight of cement can be saved by using locust bean pod solution in moulding the sandcrete blocks.
\end{abstract}

KEYWORDS: Cement, compressive strength, locust bean, sandcrete blocks, building.

[Received December 19 2015; Revised May 2 2016; Accepted May 6 2016]

\section{INTRODUCTION}

The need for locally produced, cost effective building materials in the developing countries such as Nigeria cannot be overemphasized due to imbalance between the demand for housing and the expensive conventional building materials. Shelter is one the basic needs of man and the means for possessing it is farfetched in this country especially among the teaming low income earners. The over dependence on the utilization of Sandcrete blocks for buildings have kept the cost of these blocks as walling units in buildings financially high. This hitherto, has continued to deter the underdeveloped and poor nations of the world from providing houses for their rural dwellers who constitute the higher percentage of their populations and are mostly agriculturally dependent.

The high cost of Sandcrete blocks coupled with the low strength properties of commercially available Sandcrete blocks necessitates the need for alternative low cost walling material (Aguwa, 2010). Sandcrete blocks are produced by mixing cement, sharp sand and water in a designed workable mix proportion, moulding into the desired sizes, finally watering and sun drying for some days to get the required strength. Cement, which is the binding agent in the mixture is the most costly of all and this leads the rural dwellers to building their houses with ordinary mud without cement. Such houses develop unsightly cracks and with time collapse completely rendering the occupants homeless. Also the price of river sharp sand used in the production is ever increasing due to shortage of it and cost of water used for mixing is high due to demand for production and curing. As a result of this ever-increasing

*Corresponding author’s e-mail address: jiaguwa@yahoo.com cost of these constituent production materials, coupled with the increasing high demand, the price of Sandcrete blocks has correspondingly increased. Greater percentage of the country's population finds it difficult or almost impossible to afford the cost (Aguwa, 2009).

Sandcrete blocks are produced in two major forms as dense blocks, which are made with dense aggregates as specified in BS 882 (1992) like natural sand and crushed rock and lightweight blocks that are made with lightweight aggregates or aerated concrete. Dense blocks have densities in the range of 1920 to $2080 \mathrm{~kg} / \mathrm{m}^{2}$ and may be solid or hollow. Dense solid blocks made with natural sand were used in this research work. Cement as a binder is the most expensive input into the production of sandcrete blocks and this has necessitated producers to produce blocks with low cement content, in order to be affordable to people (Hombostel, 1991). In most cases, the producers of these weak sandcrete blocks and the users lack adequate engineering knowledge on the strength quality requirements of Sandcrete blocks for buildings.

The African locust bean tree, "Parkia biglobosa" is a perenial tree legume, belonging to the sub-family Mimosodeae and family leguminosae (Campbell-Patt, 1980). Parkia biglobosa is an important multipurpose tree from the savannah zone of West Africa. The plant increases soil fertility, grows to about $15 \mathrm{~m}$ in height and has dark, evergreen, pinnate leaves. Its fruit is a brown, leathery pod of about 10 to $30 \mathrm{~cm}$ long and contains gummy pulp of an agreeable sweet taste, in which lies a number of seeds. The pods are edible and are often used for livestock feed. It is a widespread savanna tree and it is recognized easily by its bright red pendulous flowers. The doi: http:/ /dx.doi.org/10.4314/njtd.v13i1.3 
seeds of the locust bean are used for food seasoning in almost all parts of Nigeria and it is popularly known as Dawadawa in northern Nigeria while the Yorubas call it iru. As reported by Campbell-Patt (1980), the fruit is also sweet and can be consumed directly by people while the pod is used in making gums in the industries. According to Akabi et al, (2005), seeds of Parkia biglobosa were found to be rich in lipid, protein, carbohydrate, soluble sugars and ascorbic acid. Research by Aliero (2004) showed that the seeds contain 54\% fat and 30\% protein in addition to vitamins and minerals such as Calcium, Potassiun and Phosphorus. The trees serve as wind break and provide shade (Okunlola et al., 2011). Studies carried out by Tee et al. (2009) revealed that locust bean trees and ironwood trees contribute significantly to nutritional wellbeing of the people of North-Central Nigeria and that their monthly net incomes from products of these trees compared favourably with the national minimum wages of N7500 (USD59 equivalent) per month. As a result, many of them were living above the national minimum wage.

The seeds are used extensively as seasoning and also nutritious additives to soups and stews as well as good source of essential amino acids (Hassan and Umar, 2005). The fruit pulp analyzed showed moisture content of $8.41 \%$, protein $6.56 \%$, fat $1.80 \%$, crude fibre $11.75 \%$, ash $4.18 \%$ and carbohydrate of $67.30 \%$ (Gernmah et al., 2007). The locust bean seed produced by the parkia tree is embedded in a yellowish, sweet tasting edible pulp. The pods, containing locust bean seeds, resemble that of a soybean pod that starts out as a bright green and turns dry and deep brown as it matures on the tree. The pods are collected and soaked in water for at least four days and the extract is now used to mould mud blocks for building purposes.

At other times, the pods are spread over mud walls and as soon as rain begins to fall on the pods, the leachate percolates down the wall. These buildings and fence walls have been found by the natives to withstand over a long period of time under varying weather conditions such as rains, wind and heat (Aguwa and Okafor, 2012). The African locust bean (Parkiabiglobosa) has a wide distribution ranging across the Sudan and western coast of Africa in Senegal. Concentrated locust bean pod extract is used to impart water resiliency to floors, walls and ceramics pot. The tannins present in the husk act to bind the soil by their polymeric nature and render the surface impervious to water, sealant to pot and creates a dark, mottled surface.

The aim of this work is to find out the economy and effectiveness of using Locust Bean Pod Solution (LBPS) instead of water for production of Sandcrete blocks, especially if it can improve the compressive strength. Addition of cement as binder in the production of laterite blocks has been established to have significant increase in the compressive strength of the blocks (Aguwa, 2010). The objectives of the study include; carrying out extraction of active ingredients in locust bean pod, production of sandcrete blocks using the locust bean pod solution as water for mixing and carrying out compressive strength test on sandcrete blocks produced.

\section{MATERIALS AND METHODS}

Cement: The cement used for the tests was bought from a cement depot at Kpakungu village Minna, Nigeria and it conforms to the quality of Ordinary Portland Cement as described by BS 12 (1996).

Sand: Clean river sharp sand collected from a river around Gidan Kwano, Minna, Nigeria which was in conformity with the recommendations of BS 882 (1992) was used.

Locust bean pod: Locust bean pods were collected from their trees around the campus of the Federal University of Technology, Gidan Kwano, Minna, Nigeria.

Water: Tap water in Civil Engineering laboratory of Federal University of Technology, Minna was used and it was in conformity with recommendations of BS 3148 (1980).

\section{Laboratory Tests}

For the purpose of classification, the following tests were carried out on the sharp sand and Locust bean pod; particle size distribution, specific gravity, natural moisture content in accordance with BS 1377 (1990)

\section{Preparation of the Test specimens}

The epicaps (outer leathery cover of the pods) of the locust bean pods were cut to various sizes not exceeding $50 \mathrm{~mm}$ in length for the purpose of weighing. Particle size distribution was carried out before soaking for twenty four hours in clean water for the purpose of extraction in ten different concentrations of $5,10,15,20,25,3035,40,45$ and 50g/l. Five blocks of size $150 \mathrm{~mm}$ cube were moulded for each concentration of LBPS using a sandcrete block mix ratio of 1 : 6 and their compressive strengths were determined at 28 days.

Twenty sandcrete blocks of size $150 \mathrm{~mm} \times 150 \mathrm{~mm} \times$ $150 \mathrm{~mm}$ were moulded using a mix ratio of 1:6 and LBPS of concentration $50 \mathrm{~g} / \mathrm{l}$ by partially reducing $0,5,10,15,20,25$, 30,35 and $40 \%$ respectively by weight of cement, making a total of 180 blocks. In order to study the effect of longer period of soaking the locust bean pod leathery cover in water, five blocks were moulded using LBPS of concentration $50 \mathrm{~g} / \mathrm{l}$ but soaked for $1,2,3,4,5,6,7,8,9$ and 10 days respectively, making another total of 50 blocks, which were cured under sun by watering in the morning and evening for the first seven days. Hand mixing was used throughout the production and uniformity was achieved by turning the mixture from one side to the other for six times (Neville, 2000). A $2.5 \mathrm{~kg}$ rammer falling from a height of $30 \mathrm{~cm}$ was used to compact and the mould was filled in three equal layers in accordance with BS 1377 (1990).

\section{Compressive Strength Test}

The Sandcrete blocks produced to study the effect of concentration of LBPS on the compressive strength were subjected to compressive strength test at 28 days age of curing. Those moulded to study the effect of partial reduction in quantity of cement were tested on 7, 14, 21 and 28 days age of curing respectively in accordance with BS 1881Part 116 (1983) while those for studying the effect of duration of soaking the locust bean pod in water were tested on 28 days. An electrically operated Seidner compression machine was used throughout for the testing. Five blocks from each mix 
were tested in each day and the average compressive strengths were calculated. Care was taken to ensure that the critical dimensions of the blocks were maintained to assure constant area of the block in contact with the compression machine (Aguwa, 2009).

\section{RESULTS AND DISCUSSION}

Figure 1 shows the particle size distribution of the sand used in moulding the sandcrete blocks for the experiment. The sand was found to be in zone 2 in accordance with NIS 87 of 2004 and BS 882 of 1983 classifications. The specific gravity of sand is 2.7 and is in good agreement with the recommendation of BS 1377 (1990) while the natural moisture content is $11.68 \%$. The specific gravity of the sand is also in conformity with Shirley, (1975) who reported that normaldensity aggregates generally have specific gravities between 2.5 and 3.0. Chemical analysis of the locust bean pod solution by means of Atomic Absorption Spectroscopy (AAS) method, showed that it contains tannin as the active ingredient responsible for binding force.

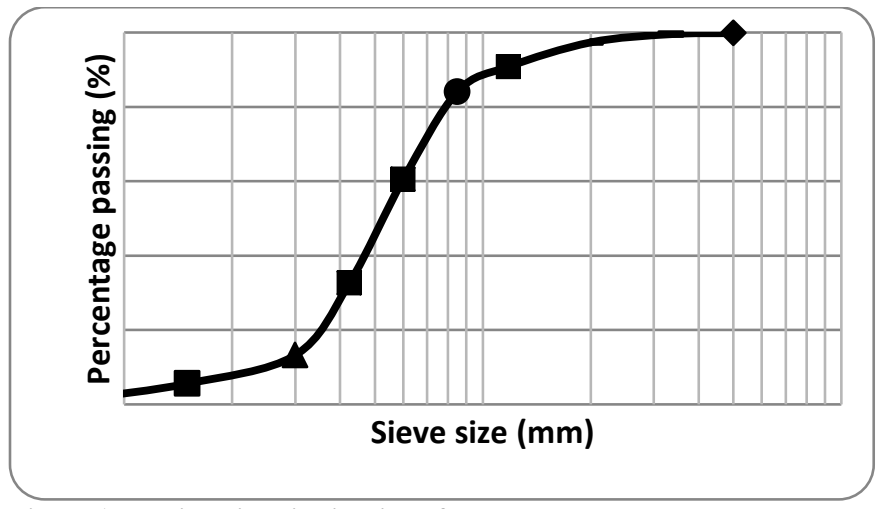

Figure 1: Particle size distribution of sand used to mould the blocks

\section{Compressive Strength}

Effect of LBPS concentration on the compressive strength of Sandcrete blocks at 28 days age of curing is shown in Figure 2 and it can be seen that the compressive strength increases with increase in concentration of the solution.

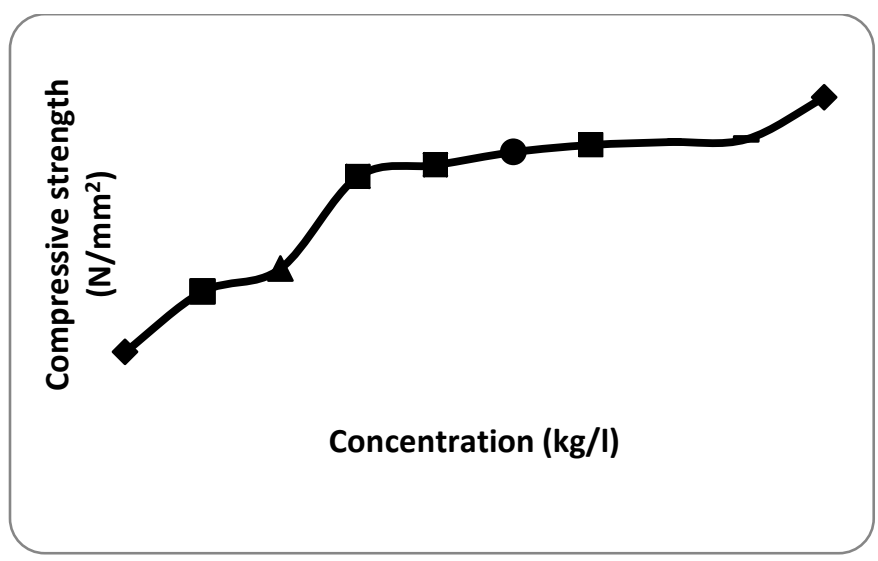

Figure 2: Relationship between LBPS concentration and Compressive strength of Sandcrete blocks at 28 days age of curing

The compressive strengths of the sandcrete blocks without and with partial reduction in quantity of cement are shown in
Figure 3. A compressive strength of $2.07 \mathrm{~N} / \mathrm{mm}^{2}$ was recorded at 28 days age of curing for $25 \%$ reduction in quantity of cement in the mix. The decrease in strength of the Sandcrete blocks as a result of the partial reduction in quantity of cement is $11.16 \%$ at 28 days age of curing. Gradual reduction in the quantity of cement in the mix can be made up to $25 \%$ if LBPS is used in mixing instead of ordinary water, without affecting the strength required for masonry works. This finding agrees with the recommendation of Nigerian Industrial Standard (NIS $87,2004)$, which states that the lowest crushing strength of individual load bearing blocks shall not be less than $2.5 \mathrm{~N} / \mathrm{mm}^{2}$ for machine compaction and $2.0 \mathrm{~N} / \mathrm{mm}^{2}$ for hand compaction.

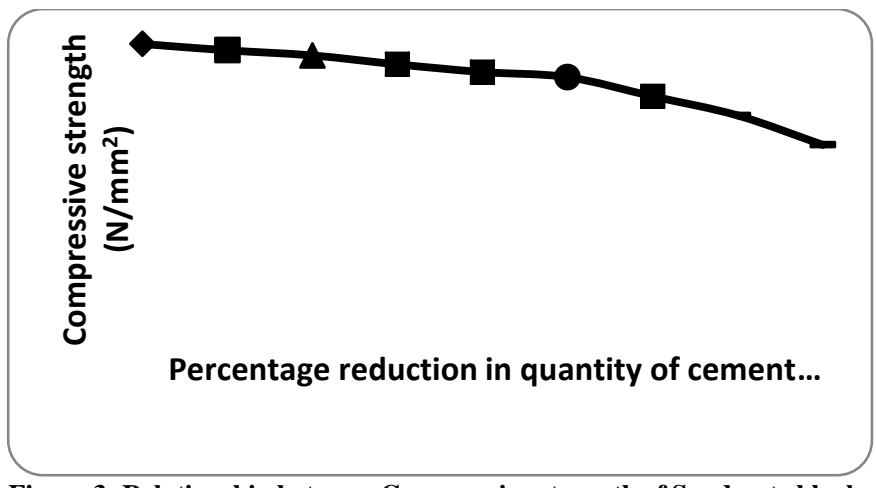

Figure 3: Relationship between Compressive strength of Sandcrete blocks at 28 days and Percentage reduction in quantity of cement.

From Figure 4, it can be seen that increase in curing age led to proportional increase in compressive strength of the Sandcrete blocks for all the mixes and this is normal with most concrete products.

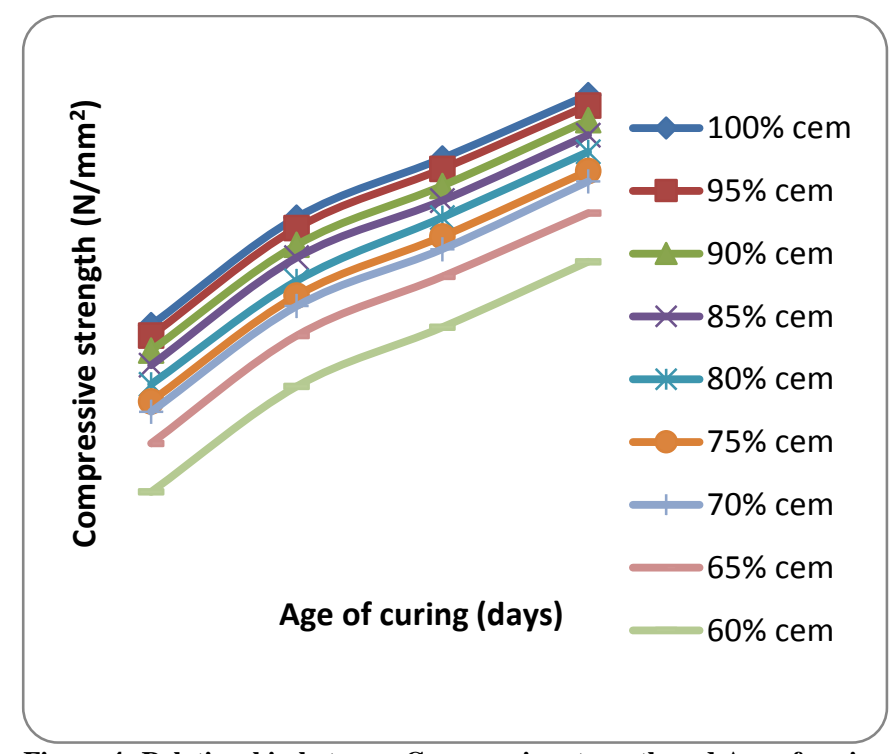

Figure 4: Relationship between Compressive strength and Age of curing for the sandcrete blocks at various percentage of cement.

Also the effect of duration of soaking the locust bean pod leathery cover in clean water is shown in Figure 5. Soaking the locust bean pod leathery cover for more than 24 hours is not necessary as the compressive strength tends to reduce as a result of longer period of soaking. This could be as a result of 
weakening the adhesive force of the tannin due to over saturation by water.

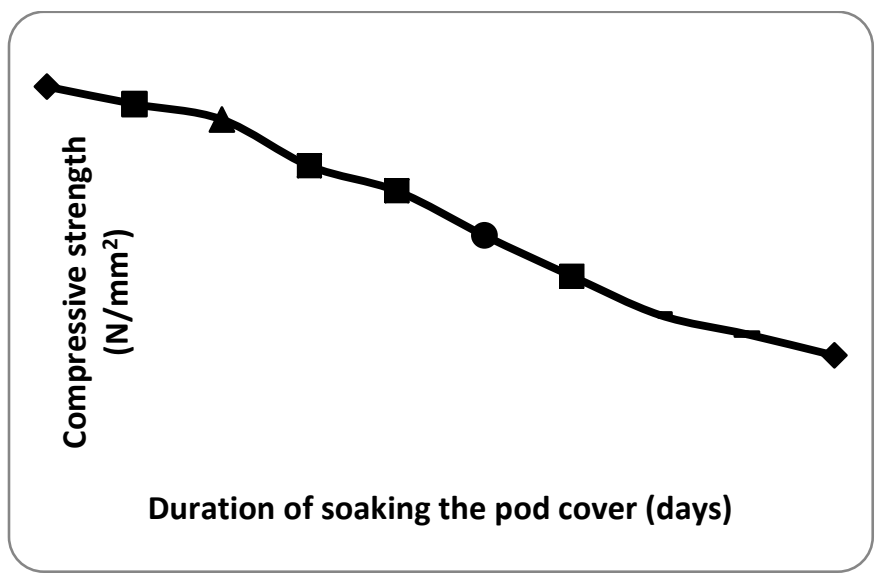

Figure 5: Relationship between compressive strength and duration of soaking the locust bean pod leathery cover in water

\section{CONCLUSION}

Locust Bean Pod Solution (LBPS) can economically and effectively be used in the production of Sandcrete blocks for buildings with some percentage reduction in the quantity of cement. The percentage reduction in quantity of cement can be up to $25 \%$ without reducing the compressive strength of the Sandcrete blocks to unsatisfactory level. Hence, the cost of sandcrete blocks can be reduced significantly by partially reducing the quantity of cement and mixing with locust bean pod solution produced by soaking the locust bean pod for not more than 24 hours. This will lead to reduction in construction cost of houses in Nigeria. This will also create employment to the rural dwellers where locust been trees are grown.

\section{REFERENCES}

Aguwa, J. I. (2009) Study of Compressive Strengths of Laterite-Cement Mixes as Building Material, Assumption University Journal of Technology (AU J.T.) 13(2), 114-120.

Aguwa, J. I. (2010), Performance of Laterite-Cement Blocks as Walling Units in Relation to Sandcrete Blocks, Leonardo Electronic Journal of Practices and Technologies, Issue 16, January - June, 2010, 189 - 200.

Aguwa, J. I. and Okafor, J. O. (2012). Preliminary Investigation in the Use of locust bean pod Extract as Binder for Production of Laterite Blocks for Buildings, International Journal of Environmental Science, Management and Engineering Research, 1 (2), 57-67.

Akabi, D.A.; O.R. Akinsulire, and M.A. Sanyaolu. (2005). Qualitative Determination of Chemical and Nutritional
Composition of Parkia biglobosa, (JACQ) Benth, African Journal of Biotechnology, 4(8), 812-815.

Aliero, B. L. (2004). Effect of Sulphuric acid, Mechanical Scarification and Wet Heat Treatment on Germination of Seeds of African Locust Bean Tree, Parkia biglobosa, African Journal of Biotechnology, 3(3), 179-181.

BS 12 (1996) Portland cement (ordinary and rapidhardening), British Standards Institution, 2 Park Street, London

BS 1377 (1990) Methods of Testing Soils for Civil Engineering Purposes, British Standards Institution, 2 Park Street, London.

BS 1881 Part 116 (1983). Methods for Determining Compressive Strengths of Concrete Cubes, British Standard Institution, 2 Park Street, London.

BS 3148 (1980) Tests for water for making concrete, British Standards Institution, British Standard House, 2 Park Street, London, WIY 4AA.

BS 882 (1992) Aggregates from natural Sources for concrete, British Standards Institution, 2 Park Street, London

Campbell-Pratt, G. (1980). African Locust Bean and its West African Fermented Products Dawadawa, Eco. Food Nutrition, 1. 9, 123-132.

Germah, D. I.; M.O. Atolagbe, and C.C. Echegwo. (2007). Ntrition Composition of the African Locust Bean Fruit Pulp, African Journal Online, Nigerian Food Journals, 25(1), 190-196.

Hassan, L. G., and Umar, K. J. (2005). Protein and Amino Acids Composition of African Locust bean, Tropical and Sub-tropical Agroecosystems, An International Multidisciplinary Journals, 15(1), 45-50.

Hombostel, C. (1991) "Construction Materials: types, uses and application." John Wiley and Sons Inc., U.S.A, p.271.

Neville, A.M. (2000) "Properties of Concrete" $4^{\text {th }}$ Ed. Pearson Education Asia Ltd, Kuala Lumpur, Malaysia

NIS 87: (2004) "Standard for Sandcrete Blocks" Nigerian Industrial Standard Approved by Standard Organization of Nigeria (SON).

Okunlola, A. I.; R.A. Adebayo, and O.D. Orimogunje. (2011). Methods of Breaking Seed Dormancy on Germination and Early Seedling Growth of African Locust Bean (Parkia biglobosa), (JACQ) Benth, Journal of Horticulture and Forestry, 3(1), 1-6.

Shirley D.E. (1975) Introduction to Concrete, Wexham Springs, Slough SL3 6PL, England.

Tee, T. N.; J.A. Oguche, and E.T. Ikyaagba. (2009). The Role of Locust bean and Ironwood trees in Human Nutrition and Income in Nigeria, Pakistan Journal of Nutrition, 8(8), 1172-1177. 